\title{
COMPANIONSHIP
}

\section{by a lay labour supporter to modify the clinical birth environment: long-term effects on}

V Cheryl NIkodem

MCur, BACur(Ed \& Comm), RM, RN

$\&$

AGW Nolte

D.Litt. et Phil

\&

W Wolman

Ph D

\&

\section{AM Gülmezoglu}

MD

\&

\section{G J Hofmeyr MRCOG}

Professor and Head, Department of Obstetrics and Gynaecology,

Coronation Hospital and University of the Witwatersrand, Medical School

Midwives should mobilize resources from within the community to give continuous emotional and physical labour support ...

\section{OPSOMMING}

Doel

Die doel is om te bepaal of die implimentering van ondersteunende kameraadskap deur ' $n$ "doula" ('n leke kraamondersteuner) aan nullipareuse vrouens gedurende baring, langtermyn psigososiale veranderinge op die moeder het.

Navorsingsomgewing

Die studie is gedoen by ' $n$ akademiese hospitaal wat hoofsaaklik aan 'n lae inkomste stedelike populasie in die Westelike voorstede van Johannesburg diens voorsien.

\section{Navorsingsontwerp}

Tweehonderd-en-sestig primigravidas wat in gestabiliseerde baring was met geen verloskundige komplikasies, en wat geen ondersteuner by haar gehad het nie, het toestemming verleen om aan die studie deel te neem. Hulle was ewekansig toegewys om addisionele ondersteuning deur 'n "doula" gedurende baring te ontvang, of die gewone standaard prosedure van verpleegsorg te ontvang. Die deelnemers en hul babas is een jaar na die bevalling opgevolg.

Hoofmeetbare veranderlikes

Voedingsgewoontes, ouerskap praktyke, self-esteem, postpartum depressie en die verhouding met haar metgesel.

\section{Resultate}

Minder vroue in die studiegroep het gerapporteer dat die verhouding met hul metgesel versleg het, en meer het hul seksuele verhouding binne twaalf weke hervat. Daar was geen ander resultate wat statistiese beduidenis getoon het nie.

Gevolgtrekkings \& aanbevelings

Hierdie studie het die langtermyn effekte van ondersteuning gedurende baring geevalueer. Verdere navorsing ten opsigte van kraamondersteuning behoort gerig te wees op die identifisering van effektiewe metodes van ondersteuning om langtermyn effekte aan te moedig.

Metodes soos die instelling van ondersteuning gedurende baring en nageboorte opvolg deur ' $n$ "doula" vanuit die gemeenskap kan ondersoek word. 


\section{Introduction}

The birth of a child and adaptation to motherhood is generally accepted to be a stressful life event. During this time women may experience significant physiological, phycological and emotional changes in their lives.

One of the most frequent complications of childbirth is postpartum depression (1). Perinatal stress, and in particularly postpartum depression have been associated with negative effects on children's cognitive and behavioural development (2). The arrival of a child frequently disrupts established marital and sexual relationships $(3,4)$. Maternal adaptation to childbirth and maternal behaviour during the early postnatal period may influence mother-infant interactions and subsequent growth and development of the child (5).

The way in which women adapt to these changes may be influenced by the support they receive during the uniquely vulnerable time of labour. Continuous support is an essential component of childbirth in many cultures especially where home deliveries take place.

Labouring women are often supported by their mothers or a family member. With the shift of the place of birth from home to the hospital, many practices have changed. Although fathers or relatives have in recent years been allowed into labour rooms, a considerable number of women still undergo labour without continuous support (6).

Hodnett (7) has reviewed 11 randomized controlled trials of support from caregivers (social or professional) during childbirth. The trials were conducted in Guatemala, Finland, South Africa, Canada, France, Belgium, Greece, and the United States, under widely diverse circumstances.

She concludes that the continuous presence of a support person during labour has positive short term effects on maternal and neonatal outcomes.

We conducted a randomized controlled trial to evaluate the effect of supportive companionship on labour and various aspects of adaptation to parenthood (8). We found that the support group were more likely to report that they felt that they had coped well during labour ( 60 vs $24 \%$, $\mathrm{p}<0.00001$ ).

At six weeks women in the support group were more likely to be breastfeeding exclusively (51 vs $29 \%, p<0.01$ ). Higher self-esteem scores ( 74.5 vs 58.8 , p $<0.0001)$, and lower postpartum depression (10.4 vs 23.3, $p<0.0001$ ) ratings were attained at six weeks postpartum by women who received support (9).

To investigate whether the above positive short term features may have self-reinforcing effects that could contribute to long-term psychosocial outcomes we have followed the women up, one year after birth. Clinical, psychological and biochemical results of the original study have been reported previously $(8,9,10$, $11,12,13,14,15)$.

Because of expected loss to follow-up, enrollment was continued after conclusion of the original study, to increase the sample size from 189 to 262 women.

\section{Research objectives}

The objective of this study was to examine whether supportive companionship given by a "doula" (lay labour supporter) to nulliparous women would have long term psychosocial effects on the mother

It was postulated that the positive short term features experienced by women who received supportive companionship by a doula during labour, may have selfreinforcing effects on feeding practices the mothers' perception of their infants, parenting practices and the mothers' relationship with their partners one year after delivery.

\section{Sample and methods}

A randomized controlled trial was conducted at an academic state hospital serving a low income, multi-cultural, multi racial urban population in the Western Suburbs of Johannesburg, running over a period of 56 months, from February 1989 through October 1993.

Table 1

Feeding practices

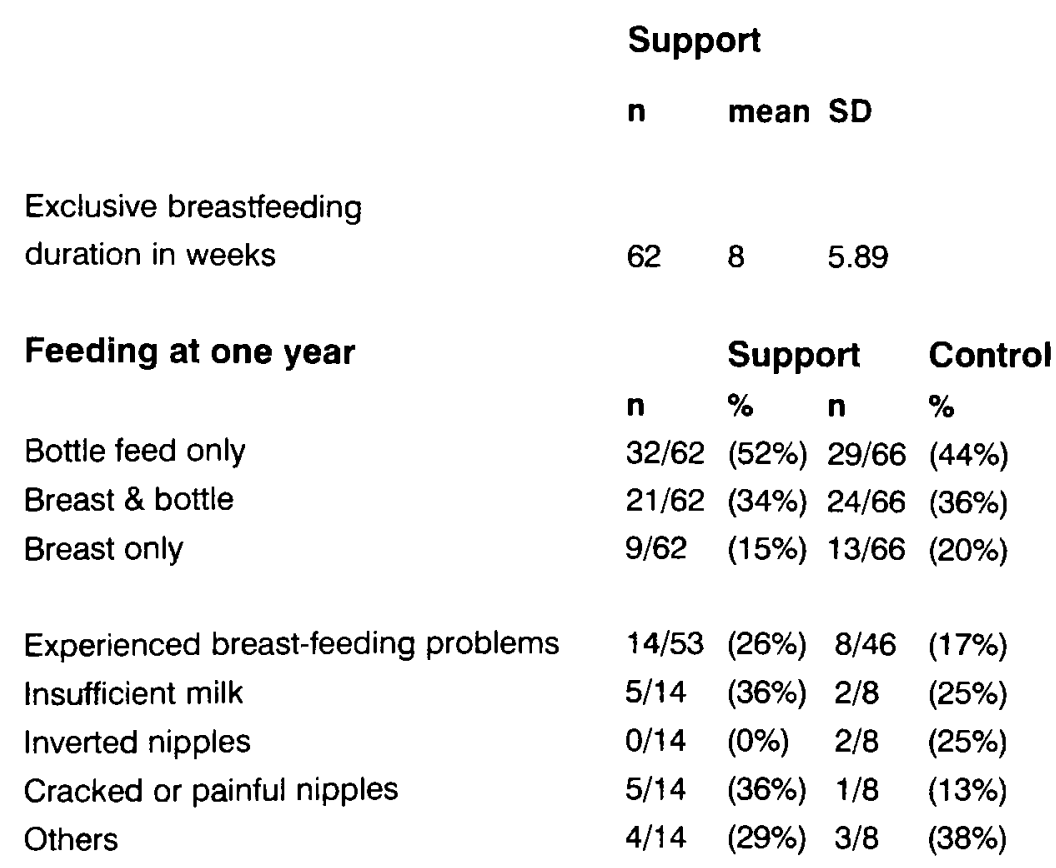

\section{Control}

n mean SD p

$\begin{array}{llll}64 & 7 & 4.68 & 0.34\end{array}$

Most common reasons for introducing bottle feeds

Insufficient milk

$16 / 47$ (34\%) 12/36 (33\%)

Going back to work

$15 / 47$ (32\%) 13/36 (36\%)

$\begin{array}{llll}1.03 & 0.37-2.86 & 0.86\end{array}$

$0.83 \quad 0.30-2.29 \quad 0.86$ 


\begin{tabular}{|c|c|c|c|c|c|c|}
\hline Outcome & Support & Control & OR & $95 \%$ & Cl & $\mathbf{p}$ \\
\hline & $\mathbf{n}$ & $\%$ & $\mathbf{n}$ & $\%$ & & \\
\hline Relation worse than before birth & $19 / 64$ & $(30 \%)$ & $25 / 65$ & $(38 \%) 0.68$ & $0.30-1.50$ & 0.38 \\
\hline $\begin{array}{l}\text { No intercourse before twelve weeks } \\
\text { after birth }\end{array}$ & $44 / 63$ & $(70 \%)$ & $57 / 65$ & $(88 \%) 0.33$ & $0.12-0.88$ & 0.02 \\
\hline
\end{tabular}

Low risk nulliparous women in established labour with cervical dilatation of less than six $\mathrm{cm}$ and who had no supportive companion with them were asked to participate in the study. The trial was verbally explained to the subjects and written consent was obtained. The subjects were informed that they could withdraw from the study at any time and that they had only have a $50 \%$ chance of receiving a labour companion.

A short baseline questionnaire was completed and baseline blood samples for the measurement of cortisol, catecholamines and endorphines were taken. An external fetal heart rate transducer and uterine contraction monitor were applied if not already in use.

Participants were then allocated to an experimental or control group by means of randomly ordered cards in numbered, sealed opaque envelopes. After the envelope was opened the patient was informed whether she would receive support from a "doula" or not. If the patient was in the control group, she was looked after by the midwifery and medical staff according to normal hospital routine.

If the patient was in the study group she received similar care, and in addition a "doula" was introduced to her. This ad- ditional support usually commenced within ten minutes after randomization.

For the purpose of this part of the study, structured interviews were conducted one year after delivery.

The interviewers were blind to the group allocation except for very few interviews in which the mother voluntarily told the interviewer that she had been allocated a "doula" during labour.

The subjects were contacted at 11 months after delivery to make an appointment for an interview at their home (support 49 , control 50 ) or at the hospital ( 59 , c5).

If it was not possible for the subject to come to the hospital or for the researcher to go to her home, the questionnaire was completed by means of a telephonic interview $(s 1, c 1)$ or an adapted postal questionnaire $(s 5, c 11)$. Three midwives were employed and trained to conduct the one year questionnaire.

Each interviewer was allocated a group of subjects to follow-up, irrespective of randomized allocation. The interview took about 40 minutes to complete. A verbal introduction was given and subjects were assured of confidentiality.

The questionnaire assessed the follow- ing principle outcomes: feeding practices, mothers' perception of their infants, parenting practices, mothers' relationship with their partners, self-esteem, and postpartum depression.

The Coopersmith Self-esteem Inventory was used to evaluate self-esteem. It measures the attitudes towards the self in domains such as social, occupational, family and personal areas of experience (17).

Postpartum depression scores at six weeks were initially measured using the Pitt Depression Inventory (18). Pitt does not describe a "cut off" point for depression. Depression is monitored in terms of changes in the individual's scores from one point of assessment to another and not as absolute values. For the purpose of this analyses we have divided the scores into two categories.

During the course of the study it was decided that the Edinburgh Postnatal Depression Scale (EPDS) (19), which had been developed specifically to assist primary health care professionals to detect mothers suffering from postnatal depression, would be more appropriate. Mothers who score above a threshold of 12 are more likely to be suffering from a depressive illness (Table 3 ).

Table 3

Self-esteem and postpartum depression

Outcome

Coopersmith self-esteem score

Post partum depression

Pitt score

EPDS score

Pitt score $>20$

EPDS score $>12$

Total high scores

\section{Support}

n mean

$63 \quad 73$

$14 \quad 13$

$48 \quad 11$

\section{Support}

n $\%$

$1 / 14 \quad(7 \%)$

$18 / 48$ (38\%)

$19 / 62$ (31\%)

\section{Control}

SD

17.52

6.97

5.31

$\begin{array}{ll}\text { n } & \text { mean } \\ 66 & 69\end{array}$

25

42
15

11
SD

18.52

5.19

.69 p

0.25

0.43

0.78

\section{Control}

n $\%$

OR

$4 / 25 \quad(16 \%)$

0.40

95\% Cl p

$16 / 42$ (38\%)

0.98

$0.02-4.72 \quad 0.39$

20/67 (30\%)

1.04

$0.38-2.5 \quad 0.87$

$0.46-2.35 \quad 0.92$ 
Statgraphics version 5.0 and Epi Info $5.01 \mathrm{~B}$ statistical programmes were used to analyze the data. Statistical comparisons of continuous variables were performed by the distribution free Mann Whitney $U$ test. Proportions were compared by means of $95 \%$ confidence intervals $(\mathrm{Cl})$ of the odds ratio (OR) and the chi-squared test.

For uniformity, results are expressed in terms of the incidence of the less favourable outcome in each case. An OR of less than one indicates a better outcome in the experimental group.

Ethical approval was obtained from the Committee for Research on Human Subjects, University of the Witwatersrand as well as from the Superintendent of the hospital.

\section{Intervention}

The hospital routine at the time of the study did not encourage a companion to be present during labour or delivery, mainly due to lack of space and privacy in the delivery rooms. Artificial rupture of membranes during the active phase of labour was used frequently. Epidural analgesia was not available, but Pethidine $\mathrm{HCL}$ and Hydroxyzine $\mathrm{HCL}$ were commonly used for analgesia. The newborn was usually taken to the nursery shortly after birth.

The mothers were moved from the labour ward directly after third stage or suturing of the perineum to the postnatal ward. The infants were taken to the mother after they had been examined, bathed and given a dextrose water feed

Mothers who chose to breast feed and who appeared to have problems were offered help by the nursing staff. Supplementary feeds were commonly prescribed by doctors.

Mothers and infants went home 24 - 48 hours after delivery. They were followed up by the district midwife for another two days, or more if needed. Participants in the support group received the same care as the control group, the only difference being the support of the doula during labour and delivery.

Continuous social support in terms of this study meant the continuous presence of a "Doula" during labour. The three doulas were mature women who had no medical, nursing nor traditional midwifery experience, but all had experienced childbirth themselves. The work was voluntary, though a small expense allowance was paid (R150 per month).

The doulas were drawn from the same community as the patients and although they were not known personally to the participants, they shared common values. The doulas were asked to concentrate on emotional support, comforting, encouraging, reassuring and praising the participant.

Tangible support included physical touch or back rubbing, assistance with changing of position, giving fluid to drink or calling the nursing staff. The doulas at no stage gave any informational support such as advice on positioning, guidance with pushing or breastfeeding advice. The doulas were introduced to the participants for the first time after randomization and stayed with them continuously during labour and in most cases during delivery.

\section{Limitations of study}

The low follow-up rate $(50 \%)$ in this study remains a matter of concern although we have no reason to believe that bias was introduced, as similar proportions of subjects were followed up (s51\% vs c $49 \%$ ), and the baseline variables of the groups followed up remained comparable. Use of two different measures of depression also limits the power of the study to detect differences.

\section{Results}

The 262 women who agreed to take part in the study were randomly allocated to a support group (s126) and to a control group (c136). Although extensive and various methods of follow up were persued, only a $50 \%$ follow up rate (s64/ 126 vs c67/136) was reached. Maternal services were not free at the time of the study and many women gave false addresses.

The population also belonged to a politically and socially disadvantage community which was very mobile.

Biographical data showed no significant differences between the two groups. The mean ages for the two groups were the same (s21 vs $c 21$ ) years.

Slightly more mothers in the support group were unemployed (s56\% vs $48 \%$ ), and similar proportions were unmarried (s71\% vs c69\%). Most women lived with their family (s65\% vs c67\%). The infants in the two groups were similar with regard to gender (s54\% vs c $49 \%$ male), weight (s10 kg vs $c 10 \mathrm{~kg}$ ) and length $(s 74 \mathrm{~cm}$ vs $\mathrm{c} 73 \mathrm{~cm})$ at one year.

Nearly half of the mothers in both groups were using bottle feeding only at one year. Mean duration of exclusively breast-feeding were similar ( 88 vs $\mathrm{C}$ $7 w k s$ ). The most common breast-feeding problems experienced were insufficient milk production and nipple problems.

The most frequent reasons given by mothers for introducing bottle feeding were insufficient milk and returning to work (Table 1).
Fewer mothers in the support group felt that their relationship with their partner was worse since the birth of the child and significantly fewer did not resume intercourse within three months of the birth (Table 2). The Coopersmith Self-esteem score did not any longer distinguish significantly between the support and control group at one year. There were no differences in postpartum depression scores between the two groups at one year (Table 3).

\section{Discussion}

The $52 \%$ overall rate of breastfeeding at one year was somewhat higher than that found in a previous survey $(39 \%)$ of a similar population by Roussouw \& Jansen (20). In the initial phase of the current study, breastfeeding at six weeks was significantly more frequent in the support group than the control group (8). The beneficial effect of labour support on early breastfeeding did not persist at one year.

The point at which mothers resume sexual relationships with their partners depends on many physical, psychologi$\mathrm{cal}$ and social factors including self-esteem and postpartum depression. Research has shown that the majority of women resume intercourse before twelve weeks, most before seven weeks post partum (21)

In our study, most of the women resumed intercourse only after twelve weeks. Fewer in the support group reported that their relationship with their partner had deteriated after the birth of the child, and significantly fewer had not resumed intercourse within three months. Support during labour may enhance the emotional readiness for the mother to resume a sexual relationship and may enhance the relationship with her partner.

It is estimated that as many as $20 \%$ of women will suffer mild to moderate depression following childbirth (22). At one year a high percentage of women $(30 \%)$ still suffered some depression.

In general, the clear-cut psychosocial benefits of labour companionship found at six weeks postpartum, such as greater self-esteem and less postpartum depression, were no longer discernable at one year.

This may in part have been due to the limited follow-up and the difficulty of measuring psychosocial parameters accurately. However, it is more likely that the benefits of labour companionship are with time diluted by the multiple other experiences and influences which may affect a mother and her child over the first year of life.

There is some evidence that ongoing support is associated with a decreased 
incidence of women's distress six months later (23).

The failure to demonstrate clear effects persisting for one year does not detract from the fact that there are clear shortterm benefits and no known risks associated with social support during labour and delivery.

Support should be available not only from those persons close to the parturient, but also from specially trained care givers such as students, midwives and lay supporters. The support given should include continuous presence, unfragmented care, reassurance, praise, encouragement and physical support such as massage or holding hands.

Midwives should mobilize resources from within the community such as the help of lay labour supporters, to give continuous emotional and physical labour support in busy labour wards where staff cannot give one-to-one care.

\section{Conclusion}

This study did not show clear effects of support during labour and delivery on long-term maternal outcomes. The potential long-term effects of continuous support during labour and delivery should be investigated further in a setting in which more women can be followed up after one year.

The potential for ongoing support in the postpartum period by the lay labour supporter, to encourage and emotionally support the woman until she has established herself in the new role of parenthood, should also be investigated. Women could be encouraged to visit primary health care centres.

Health workers at primary health care centres could be encouraged to provide facilities for counselling, and social and emotional support. The financial implications of lay supporter programmes need to be investigated.

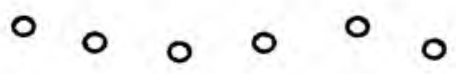

\section{Acknowledgments}

Ms K Koeberg, D Holmes and N Shultz - The "doulas" for their dedicated willingness to always be available to render the emotional support, reassurance and praise to the subjects in our study. Dr. T Kramer, Prof. B Chalmers, Ms M Adams, L Moony, U Benjamin, R Campbell, medical and nursing staff of Coronation Hospital Labour ward, for contributions to the study.

South African Medical Research Council, Rand Afrikaans University and The National Florence Nightingale Committee of South Africa, for financial assistance.

\section{References}

Trotter C, Wolman W-L, Hofmeyr J, Nikodem C \& Turton R. The effect of social support during labour on postpartum depression. South African Journal of Psychology 1992;22:3:134-138.

Garel M, LeLong N, Marchand A \& Kaminski M. Psychosocial consequences of caesarean childbirth: a fouryear follow-up study. Early Human Development 1990;21:105-114

Waldron H, Routh DK. The effect of the first child on the marital relationship. $J$ Marriage Fam 1981;43:4:785-788

Robson KM, Brant HA \& Kumar R. Maternal sexuality during first pregnancy and after chidbirth. British Journal of Obstetrics and Gynaecology 1981;88:882-889

De Chateau $P$ \& Wiberg. Long-term effect on mother-infant behaviour of extra contact during the first hour post partum Scand J Soc Med 1984;12:91-103

Keirse MJNC, Enkin M \& Lumley J. Social and professional support during childbirth. In: Chalmers I, Enkin M \& Keirse MJNC, eds. Effective care in pregnancy and childbith. Oxford: Oxford University Press, 1989;807

Hodnett ED. Support from caregivers during childbirth. [revised 05 December 1994] In: Keirse MJNC, Renfrew MJ, Neilson JP, Crowther $C$ eds. Pregnancy and Childbirth Module. In: Cochrane Database of Systematic Reviews [Database on disk \& CDROM] The Cochrane Collabration; Issue 2, Oxford: Updates Software; 1995 Available from BMJ Publishing Group, London.

Hofmeyr GJ, Nikodem VC, Wolman WL, Chalmers BE \& Kramer TR. Companionship to modify the clinical birth environment: effect on progress and perceptions of labour, and breastfeeding. British Journal of Obstetrics and Gynaecology 1991;98:756-764.

Wolman W-L, Chalmers B, Hofmeyr GJ, \& Nikodem VC. Post-partum depression and companionship in the clinical birth environment: $A$ randomized, controlled study. American Journal of Obstetrics and Gynecology 1993;168:5:1388-1393

Wolman W-L. Social support during childbirth: Psychological and Physiological outcomes. PhD Thesis. University of the Wiwaterrand, Johannesburg, 1991.

Hofmeyr G J, Nikodem V C, Mahomed $K$, Gülmezo lu A $M$, Lawson $M$, Van der Walt $\mathbf{L}$ A. Companionship to modify the clinical birth environment: no measurable effect on stress hormone levels. Journal of Obstetrics and Gynecology 1995;15:178-181.

Mahomed K, Gülmezolu AM, Nikodem VC, Wolman W-L, Chalmers BE, Hofmeyr GJ. Labor experience, mater- nal mood and cortisol and catecholamine levels in low-risk primiparous women. Journal of Psychosomatic Obstetrics and Gynaecology 1995;16:181-186.

Hofmeyr GJ, Nikodem VC, Mohamed K, Gülmezolu AM, Lawson $M$ and Van Der Walt LA. Companionship to modify the clinical birth environment: no measurable effect on stress hormone levels. Journal of Obstetrics and Gynaecology 1995; 15:178-181.

Chalmers B, Wolman W-L, Nikodem VC, Gulmezoglu AM \& Hofmeyr GJ. Companionship in labour: Do the personality characteristics of labour supporters influence their effectivness. Curationis 1995; 18:77-80.

Gülmezolu AM, Mahomed K, Hofmeyr GJ, Nikodem VC, Kramer T. Fetal and maternal catecholamine levels at delivery. Journal of Perinatal Medicine Accepted for publication 1995.

Breen D. The birth of a first child London:Tavistock Publications. 1975.

Coopersmith $\mathbf{S}$. The antecedents of selfesteem. San Francisco: WH Freeman, 1967.

Pitt B. 'Atypical' depression following childbirth. British Journal of Psychiatry 1968;114:339-346.

Cox JL, Holden LM \& Sagovsky R. Detection of postnatal depresion. British Journal of Psychiatry 1987;150:782-786.

Rossouw JPH, Jansen M. Breastfeeding in South Africa: 1987-1989 Memorandum to the director general of the department of national health and population development. Human Sciences Research Council 1990.

Robson KM, Brant HA \& Kumar R. Maternal sexuality during first pregnancy and after childbirth. British Journal of Obstetrics and Gynaecology 1981;88:882-889.

Kennedy KI. Fertility, sexuality and contraception during lactation. In: Riordan J \& Auerbach $K$, eds. Breastfeeding and Human lactation, Boston:Jones \& Bartlett, 1993;Chapter 16

Hodnett ED. Support from caregivers for distressed postnatal women / couples [revised 12 May 1993] In: Keirse MJNC, Renfrew MJ, Neilson JP, Crowther C eds Pregnancy and Childbirth Module. In Cochrane Database of Systematic Reviews [Database on disk \& CDROM] The Cochrane Collabration; Issue 2, Oxford: Updates Software; 1995 Available from BMJ Publishing Group, London. 